\title{
The Research of the Radial Growth of the Flora Species which do not Have Special Protection on the South Hillsides of Greater Caucasus
}

\section{Baghirova SB*}

Azerbaijan National Academy of Sciences, Institute of Dendrology, Azerbaijan

*Corresponding author: Baghirova Samira Behbud, Azerbaijan National Academy of Sciences, Institute of Dendrology, Baku, AZ1044, Republic of Azerbaijan, Baku, Khazar region, Settlement Mardakan, Yesenin street-89, Email: zakirakademik@mail.ru

\section{Research article}

Volume 4 Issue 1

Received Date: January 16, 2020

Published Date: February 19, 2020

DOI: $10.23880 /$ jenr-16000188

\section{Abstract}

The radial growth of the trunks of the following flora species which do not have special protection on the south hillsides of Greater Caucasus were studied in the article: Georgioan oak- Quercus iberica M.Bieb Common hornbeam - Caprinus betulus L. Common chestnut - Castanea sativa Mill. Black walnut - Juglans nigra L., Heart leaved alder - Alnus subcordata C.A.Mey. During the dendrochronological analyses, the dynamics of growth over the years were analysed based on the distances between the tree rings. The impact of the climatic factors to the growth of the trees was analysed and the ages of tree species were investigated. Based on dendrochronological historical application, according to the numbers of tree rings the ages of the trees were defined in the studied species. According to the numbers of tree rings, the oldest type of the rare and scanty flora types which have no special protection was identified as Caprinus betulus L. in Zagatala region. The tree was taken from Zagatala district, planted in 1944, was 75 years old and had $330 \mathrm{~cm}$ diameters. The observation of dendrochronological researches indicates the formation of a new microclimate. It was observed that in the investigated species, radial growth was more intense during matureness, and then it was weakened with age. In the comparative analysis, it was observed that the minimum radial growth was in 2010 and 2015, and the maximum growth was in 1973 and 1985 in the Zagatala region.

Keywords: Dendrochronology; Radial Growth; TSAP-Win; Monitoring; Climatic Factors; Phenogenetics Differentiation

\section{Introduction}

For the restoration of the soil and climatic conditions of the country, the protection as well as restoration works of existing forests together with the establishment of new forests is a requirement of the day. There has been an extensive research for studying biometric analysis and dendrochrono-lgy of processes occurring in populations of rare species of natural and cultural flora. The possibility to increase tree types that meet predetermined qualities will enable the wood to be used effectively. For this reason we have dedicated this research to the dendrochronolo-gy of the Quercus iberica M.Bieb and Caprinus betulus L. which grow in the forests in Zagatala region.

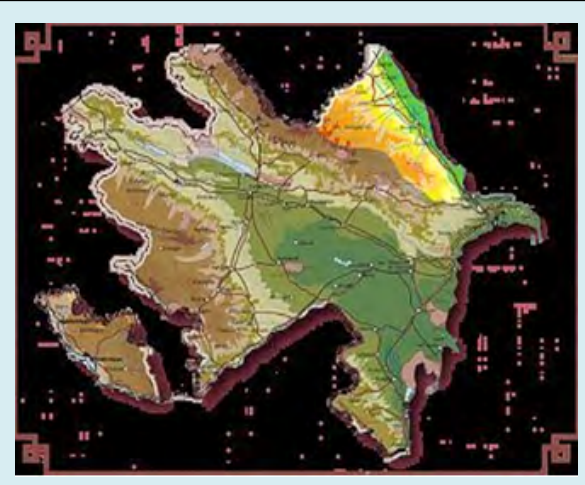

Figure 1: Phenogenetic diferentetation of the populations and recultivation of technogen landscape. 


\section{Journal of Ecology and Natural Resources}

The study of species has created conditions for the study of anthropogenic impact on the vegetation of Azerbaijan, the monitoring of the vegetation of specially protected areas, the study of the phenogenetic diferentetation of the populations and recultivation of technogen landscape.

\section{Materials and Methods}

Duringtheyear, researchersfromthe»Dendrochronology» Laboratory of the Institute of Dendrology of ANAS organized scientific trips and expeditions to various regions of the our Republic such as Zagatala and Balakan. The main purpose of dendrochronological analysis is to learn the following based on scientific facts : interactions between the trunk of the tree and environment, changeableness of the wood according to the years, the impact of the events happening due to ecological factors and tree trunk age. For this purpose, samples are taken from tree trunks, their age are defined and diagrams were set showing absolute and relative indicators of the factors affecting biological growth. This in turn, enables to define continuance criteria of the successive growth period according to the years.

In the research, the taxonomical, biomorphological, and radiological features of the species were studied based on modern equipment and TSAP-win software [1]. The average and annual indicators of the major climatic factors that affect the species most, data of central meteorological stations and indicators of the species were analysed comparatively. It was then grounded and and with the application of alphanumeric politomic assigment key which compiled based on the achieved results, the status of the species was proved and respective diagrams were setted $[2,3]$.

Phenological observations, qualitative analyzes, assessments and records in accordance with methodological guidelines were carried out during the study of rare and scant species of flora that do not have special protection status in the Zagatala region.

\section{Result and Discussion}

The studies were carried out in Zagatala in the northwest of the Republic of Azerbaijan, in the southern foothills of the Greater Caucasus Mountains, and in the east by the border with Gakh region and in the Balakan region in the west. According to the literature materials, about half of Zagatala's territory is occupied by forests located in the mountains and in the foothills. Zagatala region is rich in various types of trees such as Castanea Mill., Corylus L., Caprinus L etc. [4].

4 climate zones mainly humid subtropic and mountain tundra are typical for the area. Moderate and semi-humid subtropic climate are in plain and foothill areas and on mountainous places there are cold and humid climate.65\% of the district has a subtropical climate zone. Rich forest cover accounts for $5 \%$ of the country's forest reserves. Fagus L., Tilia L., Fraxinus L., Sorbus L. Etc tree species grow in the forests. There is Tugay forest along with Qanix (Alazan) river.

The monitoring of the areas was conducted during the research, ecosystem was assessed, rare and extinct tree and bushes were identified, old and scant types were dendrochronologically analysed and forecasts were given for these species. Samples were taken from Quercus iberica M.Bieb and Caprinus betulus L in Zagatala region (Figure 1).

In accordance with methodological guidelines phenological observations, qualita-tive analyzes, assessments, records were carried out in ANAS Dendrology Institute, «Dendrochronolgy» laboratory and in the northwest of the Republic of Azerbaijan, in the southern foothills of the Greater Caucasus Mountains, and in Zagatala which located by the border with Gakh region in the east and in the Balakan region in the west. According to the literature materials, about half of Zagatala's territory is occupied by forests located in the mountains and in the foothills. Zagatala region is rich in various types of trees such as Castanea Mill., Corylus L.,Caprinus L, Juglans L., Corylus L. Ulmus L. etc [4].

4 climate zones mainly humid subtropic and mountain tundra are typical for Balaken district. Moderate and semihumid subtropic climate are in plain and foothill areas and on mountainous places there are cold and humid climate.65\% of the district has a subtropical climate zone. Rich forest cover accounts for $5 \%$ of the country's forest reserves. Fagus L., Tilia L., Fraxinus L., Sorbus L. Etc tree species grow in the forests. There is Tugay forest along with Qanix (Alazan) river.

Containers were used to transport equipment, installations and samples to carry out scientific research in the Zagatala Balakan region [5,6].

Samples were taken from the species for getting chronological information. These samples collected in the special containers, were dried and kept in laboratory conditions.

The surfaces of the samples which were moved to containers were hewed for clear look of the wood rings and distinguishing the cells. Lintab 6 and Resistograph devices were used for setting diagrams for getting information about global changes that happened in the past based on the tree rings after samples were ready.

The main purpose of the research done in 2018 in ANAS Dendrology Institute, «Dendrochronolgy» laboratory is to biometri-cally analyze processes occurring in populati- 


\section{Journal of Ecology and Natural Resources}

ons of rare species of natural and cultural flora, their dendrochronolgical analysis, the monitoring of the areas and prepare plan for assessing and protection of ecosystems $[2,3,7]$.

Scientific trips were organized during the research of the rare and scant flora species which do not have special protection in Zagatala Balaken region,the monitoring of the areas was conducted ecosystem was assessed, rare and extinct tree and bushes were identified, old and scant types were dendro-chronologically analysed and forecasts were given for these species.

Samples were taken from Quercus iberica M.Bieb, Caprinus betulus L. Castanea sativa Mill. Juglans nigra L.
Heart leaved alder Alnus subcordata during scientific trips to Zagatala Balaken region (Figure s1 \& 2).

It was revealed from the research that the mineral content of the soil, humidity, rivalry etc. has positive impact on the growth of the species in different forms. Humidity, lack of nourishment and changeable temperature creates dense tree rings on the species which are grown in shallow soils.

The ring orders were subject to changes in years on the species which are grown in favorable conditions. The species in their growth period reacted sensitive and non-sensitively to the impact of the environment. The results are in figure Charts 1,2,3,4,5.

\begin{tabular}{|c|c|c|c|c|}
\hline No & Species & Area & Diameter of the trunk (sm) & Sample age \\
\hline 1 & Quercus iberica M.Bieb & Zaqatala. & 320 & $62(1957)$ \\
\hline 2 & Quercus castaneifolia C.A.Mey & Car forest & 330 & $75(1944)$ \\
\hline 3 & Juglans nigra L. & Balakan & 270 & $44(1975)$ \\
\hline 4 & Caprinus betulus L. & --- & 210 & $74(1945)$ \\
\hline 5 & Alnus subcordata C.A.Mey. & Zaqatala. & 392 & $85(1934)$ \\
\hline
\end{tabular}

Table 1: Area, diameter, and age of the samples.

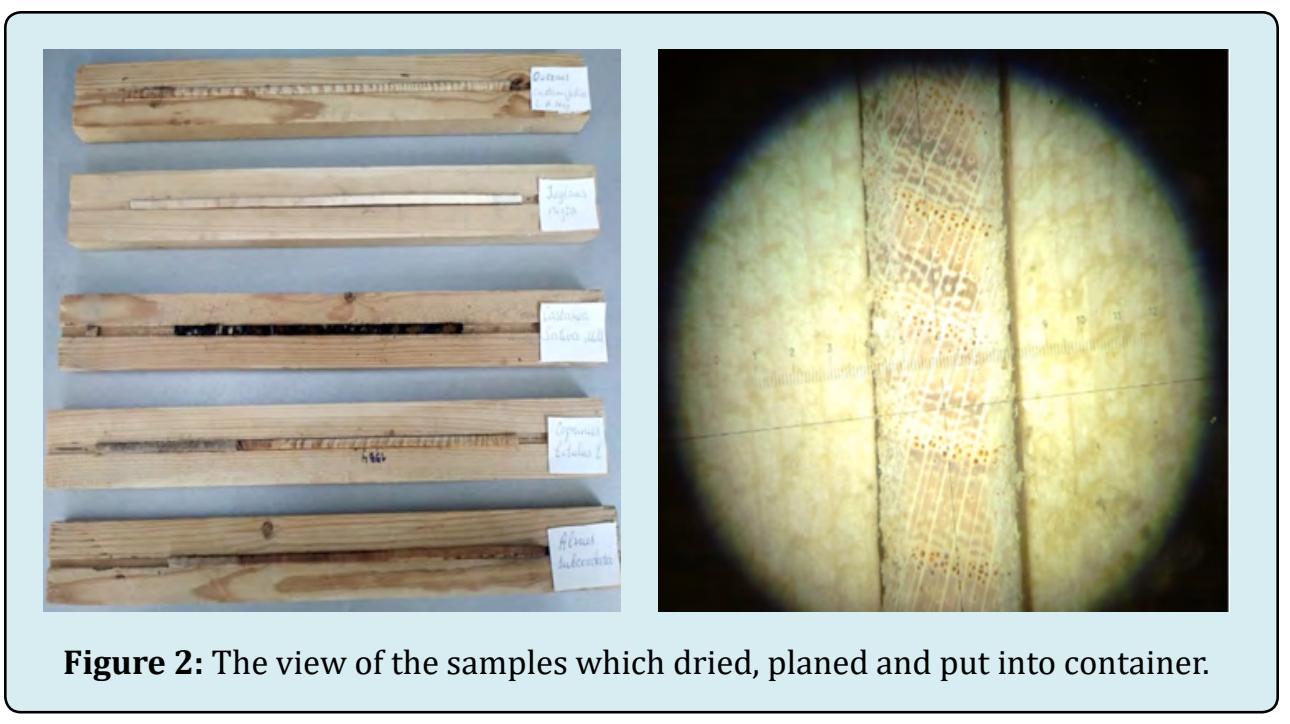

Quercus iberica M.Bieb is naturally found in Europe and the Caucasus. In Azerbaijan, it is found in the Samur-Shabran lowland, Guba, the western-eastern part of the Greater Caucasus, the northern, southern and central parts of the Lesser Caucasus and Lankaran. It can reach to $32 \mathrm{~m}$ height. Its shoots are of reddish-brown color and bare. Reproduced with seeds, the natural reproduction is good. It requires soil fertility [8].

Quercus iberica M.Bieb sample which was taken Jar forest in Zagatala was planted in 1957. It was 62 years old. It was revealed that it had grown intensively until 1975 then the dynamic of the growth decreased with age.

Quercus castaneifolia C.A.Mey is found in Iran. It is rare and relict type its natural habitat is not wide. It is found in Astara, Lankaran, Lerik, Masalli, Yardimli and Ismayilli districts. Under favorable environmental conditions, it is a tree with a height of up to $40 \mathrm{~m}$. It is one of the first tier type of trees in the forest. The young shoots are initially covered 
with dense and delicate hairs, and then they are shed. It blooms in March-April, and seeds germinate in OctoberNovember. In nature, it is mainly reproduced by seeds. It is more common in mixed forests of the Middle Mountain Range $[4,8]$.
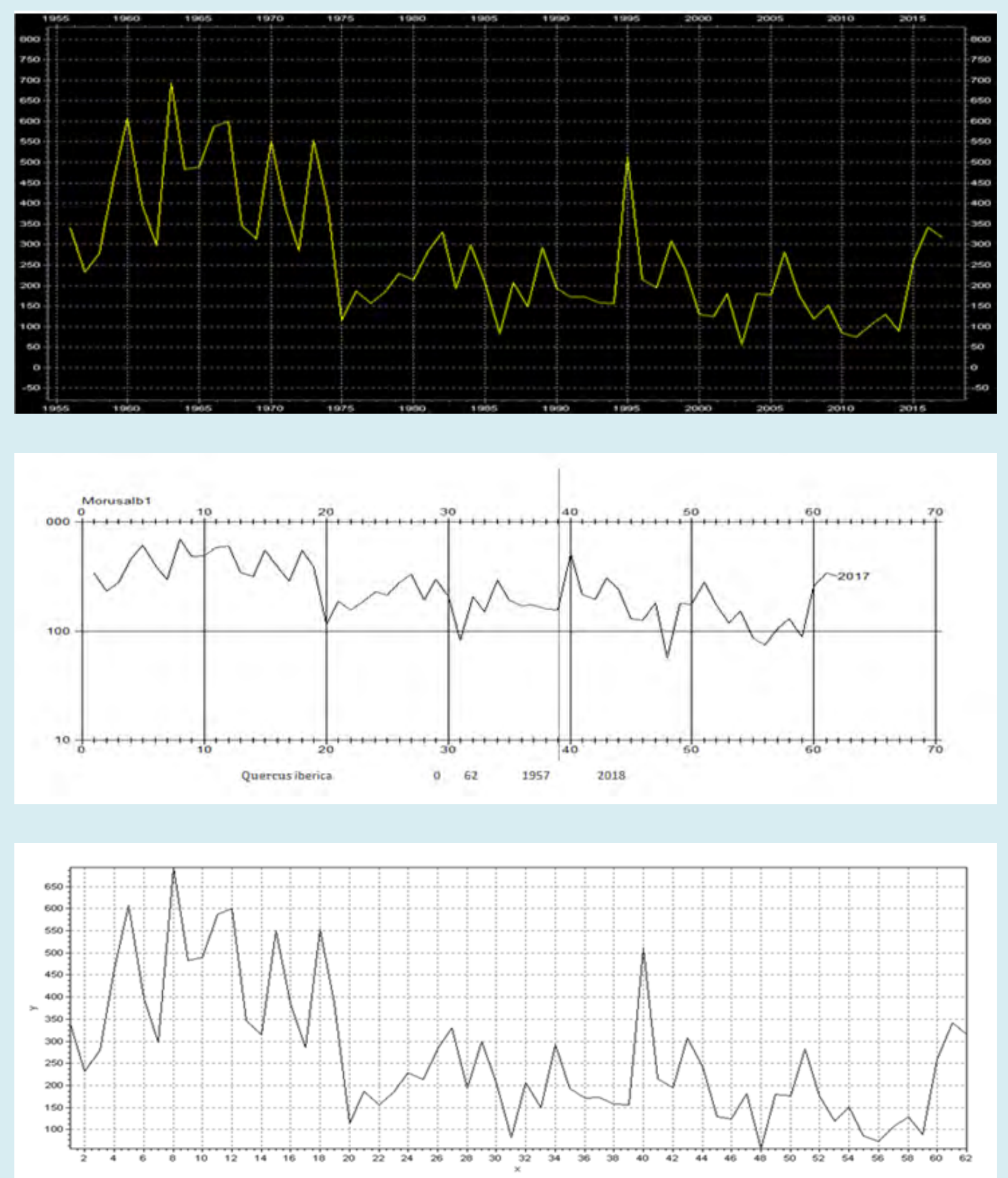

Chart 1: Quercus iberica M.Bieb radial growth inicators. 

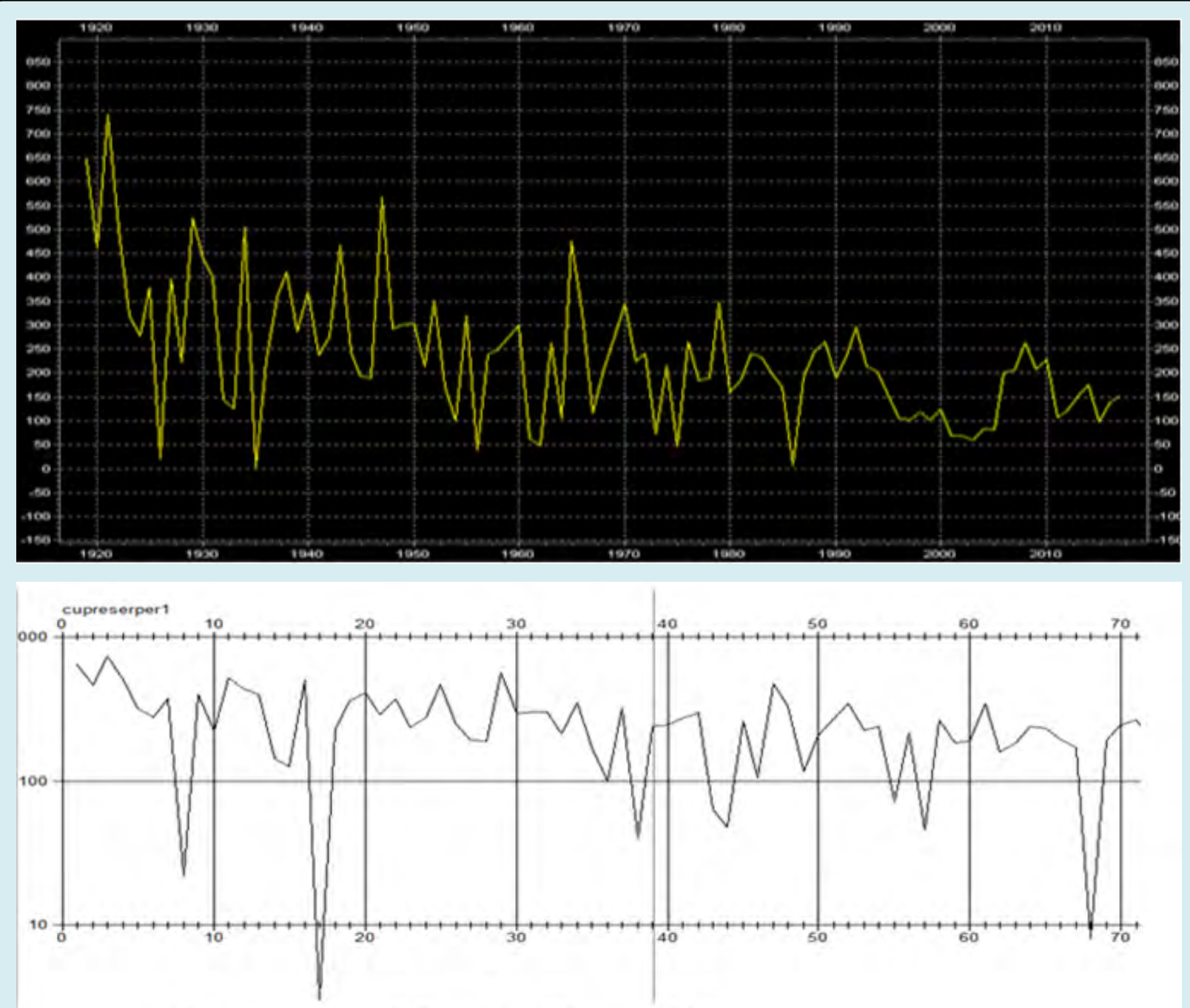

Quercus castaneifolia $\quad 0 \quad 75 \quad 1944$

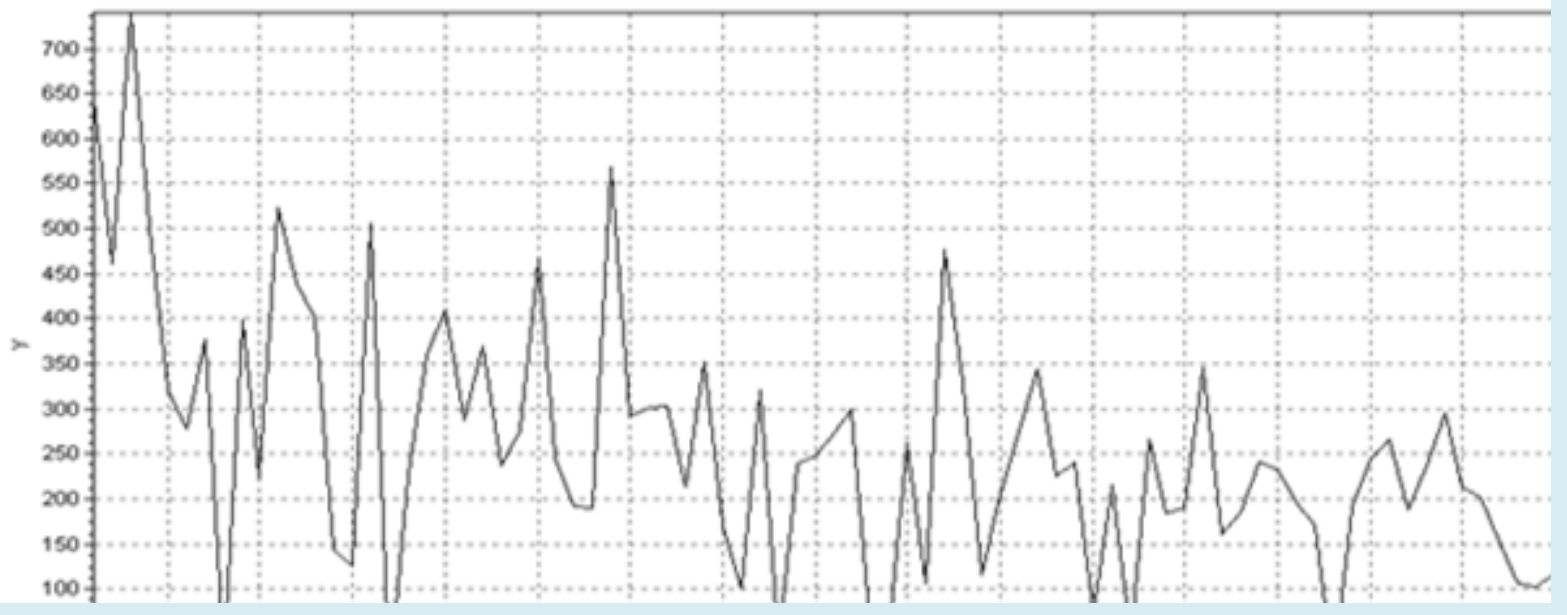

Chart 2: Quercus castaneifolia C.A.Mey radial growth indicators. 
Caprinus betulus L. - it is naturally found in Europe. The height reachs up to $25 \mathrm{~m}$. The diameter of its umbel reachs up to 7-12 meter. The annual height increase is $35 \mathrm{~cm}$. The bark is dark brown, smoother. It blossoms in May and June. The fruit ripens in September-October. It is reproduced with seeds. It is resistant to drought and frost [4].
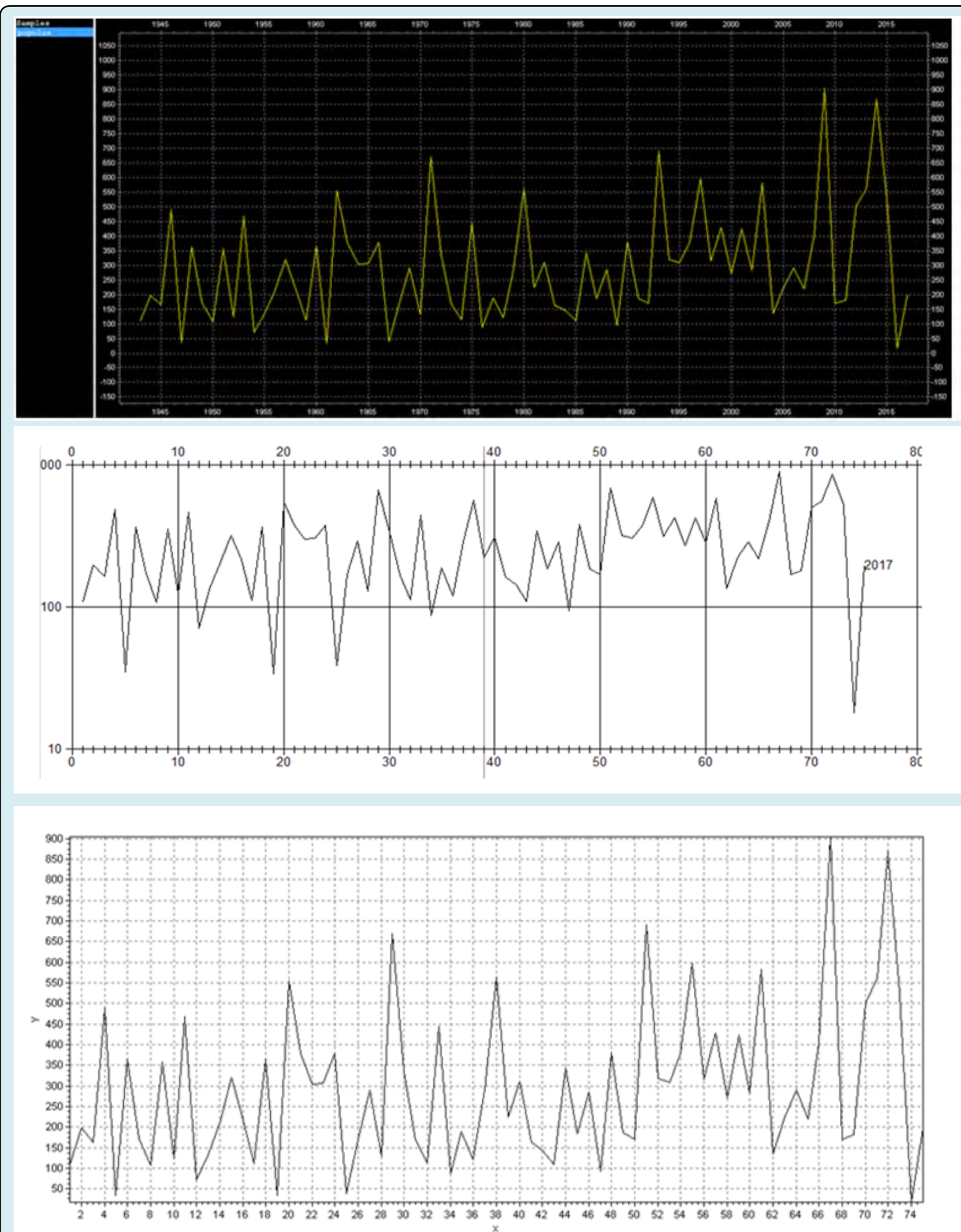

Chart 3: Caprinus betulus L. radial growth indicators. 
Juglans nigra L. its homeland is North America. It is found in Ganja, Nagorno Karabakh, Zagatala, Absheron under cultural conditions. The tree is sometimes $45 \mathrm{~m}$ high and the diameter is $180 \mathrm{~cm}$. The bark of the body is dark brown and it has uneven deep cracks. The young shoots are sparse hairy, its bud is bare.It grows in open places and has big and tent shaped umbel. It is fast-growing, frost-and drought-resistant, heliophilos and soil needing tree [4].
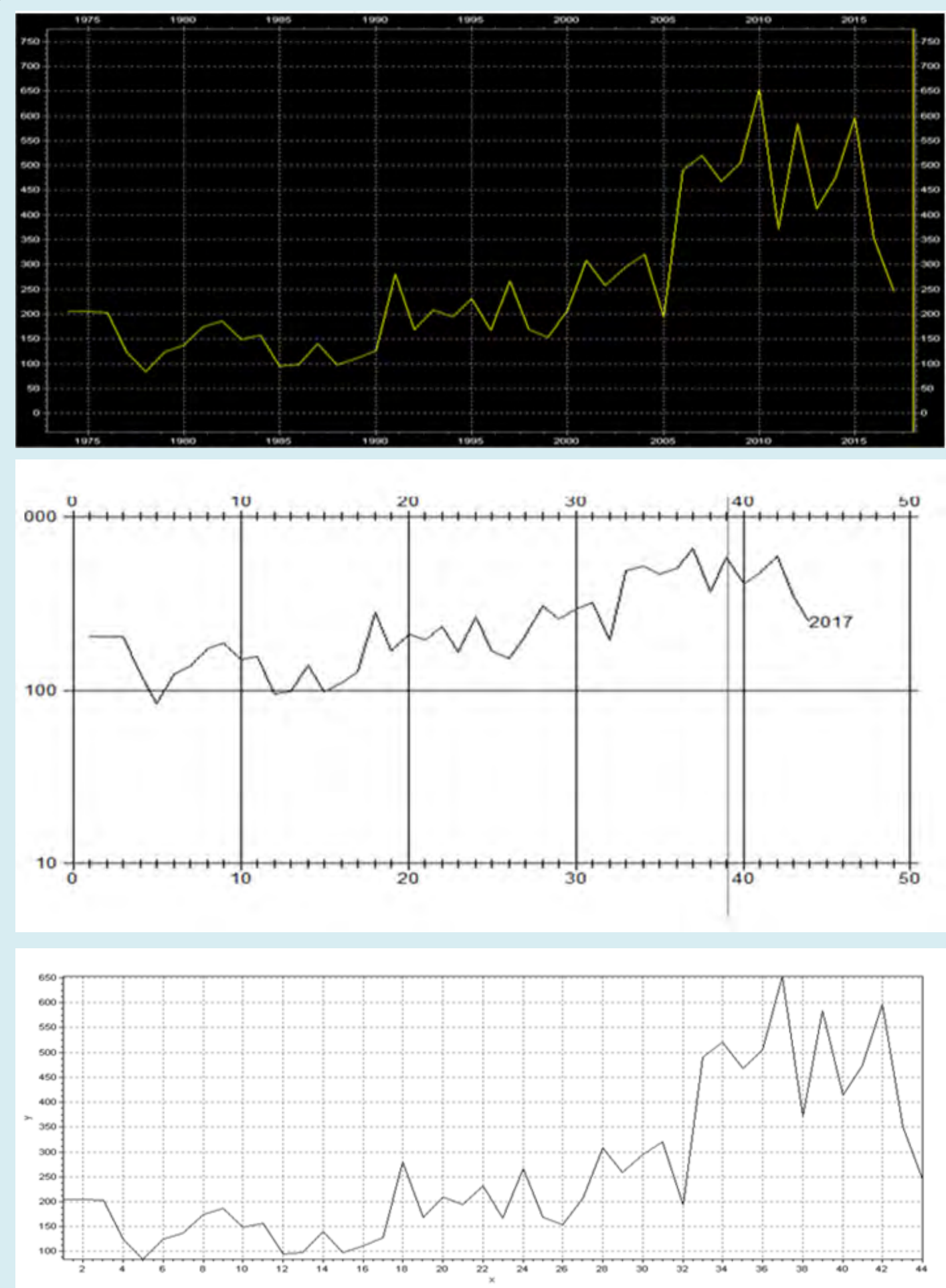

Chart 4: Juglans nigra L. radial growth indicators. 
Alnus subcordata C.A.Mey has natural habitat in Iran. It is considered as rare and relict type of tree and found in Lankaran, Lerik, Yardimli, Astara districts. It is straight-boled and reachs up to 20-30 meter height. The young trees trunk is greenish grey. Then the bark of the trunk thickens, the color becomes dark and cracks form on it. The top bud is sedentary and has no stalk. The side buds have stalks. It is reproduced by generative way. It is found in the forests, in the valleys, in humid places, on heights ranging from, low mountain ranges to moderate ranges $[8,4]$.
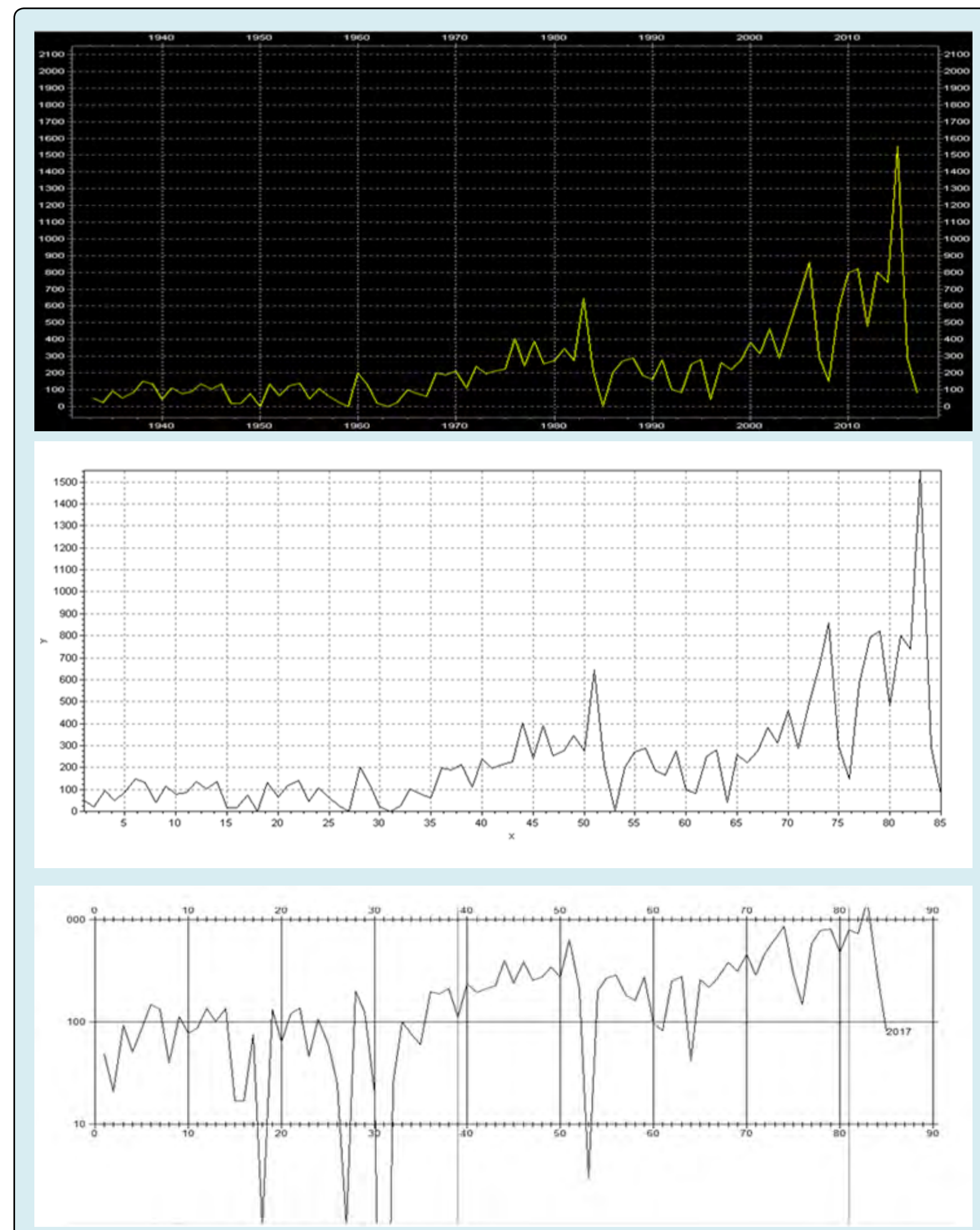

Chart 5: Alnus subcordata C.A.Mey radial growth indicators. 


\section{Conclusion}

The radila growth is fast during maturity period and getting slow with age in the studied species on Zagatala Balaken region. Based on dendrochronological historical application, according to tree rings the ages of the trees were defined in the studied species. According to the numbers of tree rings, the older type of the rare and scanty flora types which have no special protection was identified as Alnus subcordata C.A.Mey in Zagatala region. The tree was taken from Ismayilli district, planted in 1934, was 85 years old and had $392 \mathrm{~cm}$ diameters.

In the comparative analysis, it was observed that the minimum radial growth was in 2010 and 2015, and the maximum growth was in 1973 and 1985 in the Zagatala Balaken region.

\section{References}

1. Rinn F (1996) TSAP. Version 3.0 Reference manual computer program for time series analysis and presentation copyright Frank Rin Distrubution, (Heidelberg, Germany), pp: 246.
2. Mammadov TS, Isgandar EO, Talibov TH (2016) The rare trees and bushes of Azerbaijan. (Baku) Science, pp: 116.

3. Eugene AV, Spirov VV (1978) The study of meteorological conditions of the season of the tree using reflectograms of tree rings. Analysis of the dynamics of biological objects, M.: Science, pp: 103-115.

4. Mammadov TS (2011) Dendroflora of Azerbaijan 1 Volume. Science, pp: 310.

5. Campelo F, Garcia-Gonzalez I, Nabais C, Detrender AR (2012) Graphical User İnterface to process and visualize tree-ring data using, Dendrochronologia 30, pp: 57-60.

6. Schweingruber FH (1996) Tree Rings and evaronment Dendrochronology. D.Reidel Bern, (Stutgard, Wenna) Paul Haupt, pp: 609.

7. Shiyatov SG (2000) Methods of dendrochonology. (Krasnoyarsk) pp: 80

8. Mammadov TS (2010) The trees and bushes of Apsheron. Baku "Science and education" pp: 216. 